\title{
Do Women Represent Women in France? The Case of Brittany's Regional Council
}

\author{
Katherine A.R. Opello \\ Department of History, Philosophy and Political Science, The City University of \\ New York - Kingsborough Community College, 2001 Oriental Boulevard, Brooklyn, \\ NY 11235, USA. \\ E-mail: katherine.opello@kbcc.cuny.edu
}

In this paper, I examine the policies of the regional council of Brittany, France to determine whether the recent dramatic increase in the number of female officeholders resulted in an increase in women's substantive representation. I question whether the number of women-friendly policies rose after the number of female officeholders increased and if so, whether this increase is attributable to the sheer number of female councilors or to something else. I find that the number of women-friendly policies in Brittany increased when women held a majority of regional council seats, but that these policies were primarily due to the critical acts of certain male and female officeholders operating within a specific regional, national, and international political context.

French Politics (2008) 6, 321-341. doi:10.1057/fp.2008.16

Keywords: women; French regional councils; Policy; critical acts; political context; critical threshold

\section{Introduction}

Since the turn of the millennium, French women have made exciting progress in the political sphere beginning with the passage of the gender parity law in 2000, which resulted in increased numbers of female officeholders and culminating in the first competitive female presidential candidate, the Socialist Ségolène Royal, in 2007. ${ }^{1}$ Nowhere is this progress more evident than in Brittany, a mid-sized region located along France's northwestern coast, where women became a majority of regional councilors and executives after the 2004 elections. In this paper, I use an in-depth case study of Brittany to examine what happens when women outnumber men in elective assemblies. That is, I examine whether the large number of female officeholders in Brittany's regional council had a particular impact on women's substantive representation in policy terms. I find that the number of women-friendly policies increased once Breton women were in the majority, but that these policies did not necessarily result from the sheer numbers of women. Instead, they were 
mainly attributable to critical acts of individual politicians who made policy in a specific regional, national, and international political context.

I focus on France because it is one of a very small number of countries to have adopted a gender parity law, making it possible to investigate the connection between such legislation and women's representation in policy terms. ${ }^{2}$ If such a connection exists between the parity law, the increase in the number of female politicians and the passage of women-friendly policies, then parity legislation could be recommended to those seeking gender equity of political outcomes. However, if no connection is found, then scholars and activists should re-think the notion that increases in the number of women holding elective office (via parity legislation) will result in policy that affects women positively.

Following the 2004 French regional elections, the first such elections held after the passage of parity, the percentage of female regional councilors almost doubled to $47 \%$ from an average of $27 \% 6$ years before. This increase was not mirrored at the departmental and national levels where women are less than a fifth of elective assemblies; and although the number of female municipal councilors increased dramatically after the passage of the parity law, the immense number of municipal councils (approximately 36,000) precludes systematic study. ${ }^{3}$

I chose Brittany out of France's 22 regions because the increase in its female regional councilors was one of the most dramatic in France. Women comprised $22 \%$ of the regional council after the 1998 elections but were over half of all councilors after voters returned to the polls in 2004. In fact, with women holding $51 \%$ of regional council seats, Brittany was the only region to obtain absolute gender parity after the 2004 elections. I also selected Brittany because it recently experienced significant political turnover. Following the 2004 elections, the Left won control of the council for the first time since 1986, when the first direct regional elections were held. A coalition of Socialists, Communists, Radicals, and Green Party members won 58 seats while the two main parties on the Right (the Union for a Popular Movement or UMP and the Union for French Democracy or UDF) were awarded the remaining 25. Thus, in Brittany it is possible to gauge whether a relationship exists between political ideology and the creation of womenfriendly policies.

Finally, I adopted a case study approach because it can yield valuable microlevel data about the actors and institutions involved in regional policy making in general and women-friendly policy making in particular. It provides insight into whether things like personal conviction and interpersonal relations impact the policy process. These insights can give researchers a nuanced understanding of the conditions under which women-friendly policy is most likely to be made, an understanding that would be missed in a macro (or large- $n$ ) study. 
I begin with a brief review of the literature on women's substantive representation and the small number of French studies that have broached the same subject. I then provide evidence gathered from process tracing and elite interviews to show that the number of women-friendly policies in Brittany increased when women held a majority of regional council seats, but that these policies were primarily due to critical acts (i.e. acts to empower women through the policy-making process) of certain officeholders who operated within a specific regional, national, and international political context. I conclude with a brief discussion of the impact of France's gender parity laws on women's substantive representation.

\section{The Making of Women-Friendly Policy}

Studies of women and politics are usually divided into two categories. The first examines descriptive (i.e. numerical) representation or why so few women hold elective office. These studies attempt to identify the various cultural and institutional barriers that block women's entry into politics (e.g. Norris and Inglehart, 2005). The second focuses on substantive representation or the idea that women have a distinct set of interests, and that female politicians are necessary to translate these interests into policy (e.g. Phillips, 1995). Defining these interests, however, has been a topic of debate among gender and politics scholars. Generally, women's interests have been defined broadly to include both traditional women's issue areas (e.g. childcare, healthcare, education) and feminist women's interests (e.g. reproductive rights, salary equity, equal political representation). While scholars caution against assuming that women's interests are the same across time and place (e.g. Beckwith and Cowell-Meyers, 2007), it is still argued that women's interests remain gendered even though they may vary (e.g. Phillips, 1995). More recently, scholars have challenged the existing definitions of women's interests and issues. Some argue that traditional or feminist definitions are based on preconceived notions of women's interests that are 'oversimplified' and 'essentialized' (Celis, forthcoming). Others say that existing research on women's policy issues fails to acknowledge that some women organize around non-feminist or even anti-feminist goals (e.g. Beckwith and Cowell-Meyers, 2007).

Despite the debate over the definition of women's interests and whether a common set of women's interests exists, gender and politics scholars have searched for empirical evidence that female representatives act decisively on the basis of these presumed interests. In other words, they want to know whether women are more likely to pursue women-friendly policies than men. Some scholars have looked for evidence in tabulations of legislators' roll call votes (e.g. Swers, 1998). While these studies find that women are more likely to vote 
for women's policy than men, the gender differences are not very significant. Other scholars have criticized roll call studies, arguing that such votes are not the best indicator of sex differences in policy making (e.g. Tamerius, 1995). Instead of relying on roll call votes, these researchers have studied agenda setting and policy formation (e.g. bill sponsorship or introduction, bill co-sponsorship, and speechmaking) showing that women's voices are more likely to be heard and to have an impact on this part of the policy process (e.g. Bratton and Ray, 2002; Swers and Larson, 2005).

Most of the investigations into French women's political representation fall into the descriptive category (e.g. Bereni and Lépinard, 2004; Murray, 2004; Troupel, 2006). Only a small number of studies have examined the substantive representation in policy terms of French women. At the national level, evidence is mixed. On the one hand, in-depth interviews with female officeholders revealed that a large majority had no intention of pursuing policies that would improve women's lives (Sineau, 1988). On the other hand, more recent interviews with male and female members of the National Assembly showed that men and women on the Left were more likely than their counterparts on the Right to believe that women could modify the content of the political agenda, and that leftwing women were more likely to believe so than men representing the Left (Sineau, 2001). Evidence is mixed at the local level as well. A study of women elected to the municipal council in Rennes, the capital of Brittany, revealed that the female councilors added women's rights items to the agenda (Junter-Loiseau, 1998). At the same time, interviews with female mayors in rural municipalities as well as male and female town councilors suggested that they did not favor women's issues over other kinds of issues (Rieu, 1998; Lépinard, 2006). ${ }^{4}$

In addition to the works that examine whether women's substantive representation is advanced through policy making, there are studies that consider whether a specific number or critical mass of female politicians is necessary to make women-friendly legislation. Generally, it is agreed that women must comprise between 15 and $30 \%$ of a legislature to constitute a critical mass or the percentage necessary to successfully articulate policy priorities (e.g. Thomas, 1994). Empirical studies, however, call into question the concept of critical mass by demonstrating that increased numbers of women in legislative bodies do not necessarily translate into better representation of women's interests (e.g. Reingold, 2000; Carroll, 2001; Weldon, 2002), or that women could 'make a difference' even if they did not constitute a critical mass (e.g. Bratton, 2005). Instead, critical acts or 'acts of empowerment' (i.e. acts taken to mobilize the resources of the organization or institution to improve the situation for the minority group) were said to explain the advancement of women's substantive representation particularly when critical mass had not been obtained (Dahlerup, 1988). 
In the light of this empirical evidence, gender and politics scholars tried to improve upon the theory of critical mass. These scholars argue that we should re-think the idea that a critical mass of women will automatically result in an increase in women's substantive representation in general and in womenfriendly policy in particular (e.g. Grey et al., 2006; Beckwith and CowellMeyers, 2007). Instead, we should examine the ways in which internal and external political and social variables (i.e. electoral systems, political ideology, legislative norms and structures, social groups, public opinion, etc.) interact with sheer numbers of women to improve women's substantive representation. Such an examination, it is claimed, will establish 'a threshold number' (i.e. the boundary between numbers of women too small to influence lawmaking and numbers large enough to produce pro-women policy) as well as 'the conditions under which some large numbers of elected women could be translated into substantive representation of women' (Beckwith and Cowell-Meyers, 2007, 553).

In the light of these calls to improve upon the notion of critical mass, I embarked on an in-depth case study of Brittany to clarify how many women and what political conditions are necessary to produce women-friendly policy. The Breton case will reveal what impact a majority of female officeholders and a Left-controlled elective assembly have on women's substantive representation in policy terms. Additionally, my study of Brittany will improve our knowledge of women's substantive representation in France because its method of studying the subject is more comprehensive than that employed in previous French studies. These studies rely on interviews, and as a result, their conclusions are almost exclusively based on what legislators say they would (or would not) do for women in policy terms rather than on what kinds of policies were made (or not made) for women. In contrast, as discussed in the next section, I combine elite interviews with process tracing to determine whether female and male officeholders actually proposed pro-women policies as well as whether certain conditions contributed to the passage of their proposals.

\section{Research design}

To analyze the substantive representation of Breton women in policy terms, I examined two of the hypotheses generated by Karen Beckwith and Kimberly Cowell-Meyers (2007) to improve upon the concept of critical mass. The first hypothesis pertains to the political context. According to Beckwith and Cowell-Meyers, pro-women policy is more likely when leftwing parties control an elective assembly than when rightwing parties are the governing majority (557). If this hypothesis is true, then I should find evidence of an increase in the 
number of women-friendly policies in Brittany when the Left took decisive control of the council after nearly two decades of rightwing rule.

The second hypothesis deals with 'sheer numbers' or the attempt to identify a magic number above which women's substantive representation is most likely to occur. According to Beckwith and Cowell-Meyers (2007), the 'critical representation threshold' is $15 \%$. Thus, if the percentage of women elected to an assembly is $15 \%$ or higher (especially when those women are elected by leftwing parties), then women's substantive representation in policy terms will be more likely to occur than when it is below $15 \%$ (557). If this hypothesis is true, then I should find evidence of women-friendly policy beginning in 1998, when women first composed just over $20 \%$ of the regional council.

To test these hypotheses, I engaged in process tracing and elite interviewing. In other words, I used archival material, historical secondary sources, and elite interviews to determine "whether the causal process a theory hypothesizes or implies in a case is in fact evident in the sequence and values of the intervening variables in that case' (Tansey, 2007). To trace the process of women-friendly policy making in Brittany's regional council, I spent 4 weeks in the council's archives where I examined primary and secondary sources that detailed the region's policy-making process between two time periods: May 1998-May 2004 (when the Right was in power and women held about one-fifth of the seats) and May 2004-July 2007 (when leftwing parties and women had a majority of the seats). I was thus able to tabulate the number of women-friendly policies made by the council across time and to determine the source of these policies.

While previous studies of the substantive representation of women (especially those in America) investigated the agenda-setting activities of individual legislators, this method is problematic for a study of Brittany because regional councils in France function like parliaments (rather than like presidential systems). In Brittany, it is the regional council's president, aided by a cabinet of vice presidents and policy commissioners (instead of individual legislators), who sets the policy agenda and drafts the budget, which are then approved or rejected when the council meets in its tri-monthly plenary session. Moreover, given that the president leads the council's majority party (or coalition of parties), roll call votes do not provide an accurate measure of a councilor's preference since officeholders tend to vote along party lines (Lovenduski and Norris, 2003) or, as we shall see below, to vote unanimously in favor of the executive's proposals. Thus, when tabulating women-friendly policies, I focused on which members of the executive submitted the policy to the council for its approval.

In addition to my archival research, I conducted in-depth interviews with 10 sitting councilors (three of which were conducted via e-mail) and two bureaucrats hired by the national government to oversee its women's rights agenda in Brittany. I selected respondents through a process of non-probability 
sampling known as snowball or chain-referral sampling. By using a nonprobability sample, I ensured that I spoke with those individuals who were most involved in the making of pro-women policy in Brittany (which would not have been possible if a random interview sample had been generated). In particular, the snowball method (where an initial set of interview respondents suggest a second set of potential respondents who in turn suggest a third set and so on) helped me to identify those individuals who were important players in the policy-making process but who were not readily apparent upon my arrival in Brittany. I asked interview subjects a series of open-ended questions about the influence of the increased presence of women on the policy process and about the impact of several external organizations on the council's policies. These open-ended interviews served two purposes: additive and corroborative (Tansey, 2007). On the one hand, the interviews provided new information about the thoughts key elites had concerning the influx of female councilors and their potential impact on the creation of women-friendly policies. On the other hand, the interview data confirmed information that had already been collected from the regional council archives.

I defined women-friendly policies as those that advanced women's status and equality, whether in traditional policy areas (e.g. education, healthcare, childcare) or explicitly feminist ones (e.g. reproductive rights, pay equity, etc.). ${ }^{5}$ Included in these policies were those said to be gender mainstreamed by the council. Gender mainstreaming is defined as 'the process of assessing the implications for women and men of any planned action, including legislation, policies or programs in all areas and at all levels' (Rai, 2003, 16). In the case of the Breton regional council, gender mainstreaming was used to integrate gender equality into another policy area. So, for example, the region's policy on sports would include regulations or targets to achieve gender equality in athletic programs.

\section{Empirical Findings}

\section{The increase in women-friendly policies}

A tabulation of regional council policies in Brittany between January 1998 and July 2007 revealed that no women-friendly policies were promulgated when the Right held a majority of council seats (or 44 of 83 seats). Instead, during the 6-year session that lasted from May 1998 until May 2004, the rightwing council focused on the following three policy areas: improving professional development for young people, making Brittany economically competitive, and beefing up regional planning and internal development (e.g. CRB, 1999, no. 240; 2000, no. 254). Attempts to advance women's status or equality were entirely absent from these proposals despite the fact that the council approved a report 
(drafted by the regional economic and social council or CESR) on the creation of equal opportunities for men and women in Brittany. ${ }^{6}$ However, when a coalition of leftwing parties took over in May 2004, the number of womenfriendly policies gradually increased: four such policies were passed in 2004, six in 2005, 10 in 2006, and five in the first half of 2007. These women-friendly policies fell into three categories, each of which is discussed below.

\section{Gender mainstreamed policies}

The first set of gender mainstreamed policies originated in the regional council executive: President Jean-Yves Le Drian and his cabinet of 15 vice presidents. Most of these mainstreamed policies were found in the council's budget, which is drafted by the executive. As when the Right controlled the council, the Left subdivided its budget into 12 policy areas (i.e. regional planning, economic development, professional development, education, transportation, environment and tourism, cultural and athletic programs, solidarity within Brittany, inter-regional and international cooperation, scholarships, public relations, and miscellaneous expenditures). However, unlike the Right, the Left included a gender plank in three of the 12 policy areas. The first, economic development, aimed at improving the life of working women by, for example, reorganizing the workday to better meet the demands of work and family life. A goal of the second mainstreamed policy, job training, was professional equality between men and women (which could be achieved, in part, by requiring council-funded employers to recruit and train men and women equally). Finally, the educational policy included the establishment of Karta Bretagne, a program that required participating high schools to foster gender equity among students and prevent sexist behavior as well as sexual violence (CRB, 2005, no. 325; 2006 no. 341; 2007, no. 354).

In addition to these budgetary measures, the executive successfully presented two other gender mainstreaming initiatives: an athletic policy that included proposals to augment the number of girls and women in sports programs; and a strategy on jobs and job training, central to which was a quality employment charter that advocated equality between men and women in the workplace (CRB, 2006, no. 346; 2007, no. 329, no. 354).

The second set of gender-mainstreamed policies resulted from collaborations between the regional council president and the regional prefect, an appointee of the conservative national government. ${ }^{7}$ This collaboration took two forms. The first, State Strategic Action Projects in the Region (PASER), articulated the main objectives of the national government in Brittany and the means of achieving them through regional-level policy. Gender mainstreaming was first made prominent in the PASER covering 2004-2006 because one of its employment policy objectives was the gender parity of state administrators 
assigned to Brittany (Junter and Kieffer, 2006). The second, the Contract of State-Region Projects (CPER), outlined how the national government and the regional council would co-finance a set of mutually agreed upon policy objectives. In the current CPER, which covers 2007-2013, gender mainstreaming is prominent for the first time because workplace equality between men and women was included in the list of economic policy goals (CRB, 2007, no. 357).

The final set of gender mainstreamed policies originated with actors and institutions outside of Brittany. The first of these, the Charter of Decentralized Cooperation for Sustainable Development, was drafted by three organizations that represented France's various territorial units and was signed by several sub-national governments. It called for its signatories to collaborate with their counterparts in France and the European Union (EU) to achieve ecologically sound development, which rested in part on the creation of equal relations between men and women. The second agreement adopted by the council was Agenda 21, a regional version of a plan drafted at the 1992 United Nations Earth Summit. Brittany's draft had three objectives (ecological integrity, equality between nations and people, and economic effectiveness) that were gender mainstreamed; that is, gender equality between men and women, especially in the workplace, was necessary to fulfill the Agenda's goals. Third, the council voted to sign the European Charter for Equality between Men and Women in Local Life. Drafted and circulated by the Council of Communes and Regions of Europe (CCRE) with help from the EU, the Charter pledged to establish gender equality in all aspects of life by gender mainstreaming of political, economic, social, and cultural policies (CRB, 2005, no. $324 ; 2007$, no. 349 ).

\section{Specific measures to advance women's status and equality}

The second category of women-friendly policies consisted of specific measures to advance women's status and equality. These measures originated with actors and institutions within Brittany. First, the council voted unanimously to create a regional council on gender equality (known as $\mathrm{CpeG}$ ). Part think tank, part networking site, and part pressure group, the gender equality council consists of a variety of actors (e.g. local elected officials, state administrators, and interest groups representatives) who work together to identify and combat gender inequities in Brittany. The idea for $\mathrm{CpeG}$ came from the president of the regional council, Jean-Yves Le Drian, and Gaëlle Abily, the vice president for Professional Equality and Quality Employment, who commissioned the CESR to draft a report on how such a council could best be realized (CRB, 2005, no. 322). Once the report was complete, its recommendations, backed by Le Drian and Abily, were unanimously accepted by the regional council. Similarly, a few years later, the council unanimously approved the suggestions 
made in a report on ending violence against women in Brittany. This report was commissioned by Vice President Abily and strongly backed by herself and President Le Drian prior to its presentation before the council. The report's recommendations included waging a public awareness campaign, especially among young people; supporting groups already mobilized around the issue; and cooperating with existing anti-domestic violence networks at the national, European, and international levels (Abily and Pondemer, 2006).

In addition, following the recommendation of the CESR, the regional council adopted an agreement signed by the council's president, Jean-Yves Le Drian, and the then regional prefect, Bernadette Malgorn, to revive the regional parity observatory, which was created in the mid-1990s to promote the equal participation of men and women in political, social, and economic life and to integrate the principle of equality in all public policies (CRB, 2005, no. 328). The regional council also adopted an agreement co-signed by President Le Drian, Prefect Malgorn, and the superintendent of Brittany's schools to achieve equal opportunities for boys and girls in high schools (CRB, 2005, no. 328). Since both proposals were endorsed by Brittany's leftwing officeholders (i.e. the council's president) and rightwing political appointees (i.e. the regional prefect), it is not surprising that the council voted in their favor.

\section{Women-friendly funding decisions by the permanent commission}

The third category of women-friendly policies in Brittany consisted of decisions made by the permanent commission to fund groups, activities, and research seeking to advance women's status and equality. ${ }^{8}$ In 2005 , the commission gave money to the women's groups participating in International Women's Day activities, to one group distributing information about violence against women, and to a project helping women in the workplace (CRB, 2005, no. 335; 2006, no. 337 , no. 340). In 2006, funds were awarded to local universities to study gender equity issues, to a women's group campaigning against domestic violence, to the committee organizing the region's Biennials for Equality between Women and Men, to a women's group protesting sexist toys, and to a project helping women in the workplace (CRB, 2006, no. 347, no. 348; 2007, no. 350 , no. 352 ). In 2007 , monies were granted to a project to help women in the workplace and to the organization of the region's Biennials for Equality between Women and Men (CRB, 2007, no. 358).

\section{Critical actors and the increase in women-friendly policies}

The above description of women-friendly policies reveals that many of these policies came from the region's executive (i.e. President Jean-Yves Le Drian, 
the 15 vice presidents, and the permanent commission) and from national government appointees (namely, the regional prefect). My tabulation of these policies according to source revealed that a large majority of women-friendly policies $(72 \%)$ originated in the executive. Of these executive decisions, $32 \%(8 / 25)$ were gender mainstreaming policies, $32 \%(8 / 25)$ were decisions to fund women's groups, and $8 \%$ were specific measures to improve women's status and equality (e.g. gender equality council and ending violence against women). My tabulation also showed that collaborations between the regional prefect and the regional executive were responsible for the second largest number of women-friendly policies in the region $(16 \%)$.

Given the policy-making process at the regional level in France, it is hardly surprising that the executive was responsible for most women-friendly policies. As previously mentioned, regional policy does not begin with individual legislators. Instead, regional council presidents, aided by their vice presidents and the permanent commission, are responsible for drafting bills, which are then presented to the council for a vote. Once we consider the type of executive that took power in Brittany in 2004, the increase in women-friendly policies comes as even less of a surprise.

President Le Drian, a member of the Socialist Party, was widely known in the region as someone who wanted to improve the status and equality of Breton women. This was first apparent in his decision to make Brittany one of only two French regions to more than achieve the gender parity of vice presidents. Out of 15 vice-presidential slots, Le Drian gave $8(53.3 \%)$ to women and (for the first time) charged 1 with improving the status and equality of women. In addition to making gender equity a priority in his cabinet, President Le Drian backed women-friendly policies himself. As mentioned above, he signed two agreements to improve women's status by reviving a gender parity observatory and creating equal opportunities for boys and girls in high schools, he presented gender mainstreamed budgets, and he signed policy agreements with the national government (e.g. PASER and CPER) that included gender mainstreaming.

Le Drian also articulated his commitment to women-friendly policy in his written communications. In a letter to the president of the CESR, he stated that he wanted to end gender inequities in the work place and that he hoped the CESR would help him create an equality council that would do so (Saglio, 2004). In an announcement to the regional council about workplace equality, Le Drian reemphasized the region's commitment to professional equality: 'A general principle of non-discrimination between men and women [established by the national government] guarantees equal rights in the workplace... The region will continue to contribute to initiatives aimed at reducing all discrimination between men and women at work... It will help reduce inequalities in job placement, remuneration, job training, promotion 
and time management' ('Communication' 2007). He also reinforced the region's commitment to equality as outlined in the European Charter for Equality between Men and Women in Local Life: 'Equality between women and men is a democratic objective, which society must translate into daily acts. Where it is put into place, it permits the development of business and economic effectiveness' ('Communication' 2007).

A large majority of interview respondents $(71 \%)$ said the feminization of regional policies after 2004 was due to Le Drian's political will. One female councilor said he went 'all the way' when it came to gender parity while another described him as 'an enlightened executive' because of his desire to improve the condition of Breton women. An interview with Mr. Le Drian's wife, who held posts in both the regional and municipal councils, was particularly revealing. She attributed the rise in women-friendly policy to the 'political will' of her husband while admitting that she exerted an influence on his thinking. In the mid-1990s, she had worked on improving women's status at the municipal level, and she says discussions of her work with Le Drian raised his awareness of gender equity issues. In her view, these conversations (carried out over the course of their decade long relationship) are a main reason why Le Drian took pro-women actions once he became council president. ${ }^{9}$

President Le Drian was aided in his work by the regional vice president for Professional Equality and Quality Employment, the young Communist, Gaëlle Abily. Abily, with the help of her staff (most notably Frédérique Pondemer, the state administrator in charge of equality issues), played a key role in feminizing the council's policies. As described above, Abily's office commissioned reports on key women's policy issues (e.g. gender equality, especially in the workplace and ending violence against women) and oversaw the adoption of their recommendations by the council. In addition, she raised regional awareness about gender inequities by hosting public events such as the Biennial for Equality between Women and Men. Finally, the gender mainstreaming of regional policy can be attributed in part to her office, which adopted and lobbied for the approach beginning in 2004 (Abily and Pondemer, 2006).

Abily also voiced her support for improving women's status and equality in various speeches and written communications. For example, in a 2005 speech commemorating International Women's Day, Abily stated her firm conviction that gender equality is essential to human equality, and that policies should be gender mainstreamed because "women do not form a social category, an isolated social group and even less, a minority [group]' (Abily and Pondemer, 2006).

Moreover, in remarks made marking the start of the 2006 Biennial for Equality between Women and Men, Abily reemphasized the council's commitment to following through on its commitment to gender equality with a series of actions (Regional Council of Brittany, 2006). 
Finally, evidence of Abily's commitment to improving women's status was found in interviews with regional councilors. A large minority of interview respondents $(41 \%)$ stated that Abily was a major source of women-friendly policies. Moreover, in an interview, Abily claimed credit for the recent spate of pro-women policies. According to the vice president, gender parity in the regional council and its executive gave Brittany 'visibility and legitimacy,' and made gender equality in politics 'more normal.' At the same time, Abily argued that parity would not necessarily change people's mentalities and that policies would not change automatically because the number of women increased. Instead, she attributed the increase in pro-women policy to her vice presidency and its backing by the council's president.

The last source of women-friendly policy found in the executive is the council's permanent commission, which was responsible for allocating funds to a variety of women's groups. The commission comprises 35 representatives: President Le Drian, the 15 vice presidents (including, of course, Gaëlle Abily), presidents of the six policy commissions, the budget reporter, and 12 councilors. The Left holds a large majority of commission seats $(70 \%)$ with women in just under half $(43 \%)$ of them. Given that the commission includes the two biggest supporters of pro-women policy, and that leftwing parties tend to be more hospitable to pro-women policy than those on the Right, it is hardly surprising that the commission decided to fund women's groups seeking to advance women's status and equality.

This evidence suggests that the increase in women-friendly policy in Brittany after the 2004 regional elections was due in large part to the critical acts of two members of the regional executive: Jean-Yves Le Drian and Gaëlle Abily. However, these officeholders did not act alone. They were aided by representatives of the state, like the regional prefect. Bernadette Malgorn, the prefect from 2002 until 2006, was personally involved in crafting two women-friendly policies that were eventually approved by the regional council. As described above, Prefect Malgorn co-signed (with President Le Drian) agreements that would revive the regional parity observatory and create equal opportunities for boys and girls in high schools. In addition, she (along with President Le Drian) ensured that the PASER for 2004-2006 included measures to achieve gender parity in decision-making posts, especially those in the state's administrative offices. Malgorn asked one state administrator under her supervision, Françoise Kieffer, the regional Delegate for Women's Rights and Equality since 1999, to achieve PASER's objectives. In response, Kieffer collaborated with 'equality correspondents' appointed to each state office in Brittany. These correspondents were responsible for collecting sex-based statistics on hiring practices, recruiting and training more female job candidates, and encouraging existing employees to keep the national Equality Charter in mind when implementing regional council policy (Saglio, 2004; 
Junter and Kieffer, 2006). Finally, Jean Daubigny, who succeeded Malgorn as prefect in 2006, endorsed the CPER for 2007-2013, part of which sought to gender mainstream the region's employment policy.

Both Kieffer and Malgorn voiced their support for women-friendly policy. During an interview at the National Assembly, Malgorn asserted that she had made gender equity a priority for the national government in Brittany, and that even though gender inequalities persisted because of stereotypes, gender parity (as overseen by an observatory) was one of the levers of progress (Zimmermann, 2006). According to Kieffer, the PASER was an example of 'the concrete integration of equality in regional development' and was 'an example worth imitating' (Junter and Kieffer, 2006). Moreover, in our interview, Kieffer argued in favor of gender parity everywhere (not just in political life), and said parity was justified because it would achieve social justice and equality. 'Women are 50 percent of humanity after all,' she said. ${ }^{10}$

Regional councilors also asserted that state administrators were partly responsible for the spike in women-friendly policy since 2004. Specifically, a large majority $(70 \%)$ of interview respondents said that Prefect Malgorn played an instrumental role in persuading the regional council to pass prowomen policy. Moreover, Kieffer herself attributed the PASER's focus on gender parity to the prefect. Describing Malgorn as 'pregnant' with the idea that gender-based inequalities prevented the achievement of fundamental human rights and the renewal and modernization of public policy, Kieffer said that it was the prefect's 'will' that made the progression of gender parity in the region possible through the revival of the regional parity observatory and the PASER (Junter and Kieffer, 2006, 45).

Thus far, this analysis has shown that a large majority of women-friendly policies resulted from the critical acts of political officials, namely council President Le Drian and Vice President Abily as well as the former regional prefect, Bernadette Malgorn. Data collected from regional councilors echo this finding. Almost all interview respondents $(86 \%)$ volunteered that the critical acts of specific officeholders (such as Le Drian, Abily, and Malgorn) were a major reason why pro-women policy spiked in the past few years. At the same time, these critical actors need to be placed in a political context.

\section{Political context and the increase in women-friendly policies}

In Brittany, women-friendly policy decisions were not made in isolation. Rather, my interviews and archival research revealed that the critical actors described above operated within a three-layered political context: regional, national, and international. That is to say, women-friendly policies were made at a time when the Left controlled the regional council, when the conservative national government was promoting its Equality Charter, and when European 
and international organizations were presenting gender mainstreaming initiatives to the sub-national level. These three factors combined to create an environment that was amenable to the passage of pro-women policies.

It was hypothesized earlier that women-friendly policy was more likely when leftwing parties controlled an elective assembly than when rightwing parties did so. The case of the Breton regional council supports this hypothesis. As previously stated, following the 2004 regional elections, the Left won control of the council for the first time since direct elections were instituted in 1986. Moreover, with $70 \%$ of seats (58/83), leftwing parties enjoyed a sizable governing majority. Given that there were no women-friendly policies when the Right controlled the council from 1998 until 2004 and that these policies appeared regularly after the Left's strong electoral victory in 2004, then it is likely that the passage of women-friendly policies in Brittany was due in part to the new political ideology.

This finding is in keeping with the scholarly literature on gender and political parties, which has shown that leftwing parties favor policies promoting women's status and equality (i.e. the liberalization of divorce and abortion laws, the expansion of employment and educational opportunities, measures to end sexism in schools and violence against women, gender-based quotas, etc.) to a greater extent than those on the Right (e.g. Lovenduski and Norris, 1993; Ortbals, 2008). My interviews with council members echoed this scholarly literature. Three councilors said that it was 'inevitable' that policies would change once the Left took power. In the words of one respondent, women-friendly policies were due 'above all' to the political will of the leftwing parties that 'without doubt' had more interest in social questions than those on the Right. Or as another respondent explained, 'the change in policy is principally linked to the alternating of the Left and the Right. In such electoral upheaval (Brittany had never been led by the Left before), it is difficult to perceive which changes are linked to the presence of women.'

While women-friendly policies are usually attributable to leftwing parties, these policies are not entirely absent from rightwing agendas, especially if there are electoral incentives to include them (e.g. Opello, 2006). In fact, shortly before the Left won control of the Breton regional council, the conservative national government unveiled an Equality Charter. This document called upon state actors (i.e. national, regional, and local governments) as well as non-state actors (i.e. corporations and civic groups) to support the government's effort to implement over 300 initiatives, which would create gender equality in politics, the economy, and society through gender mainstreaming. The Charter was endorsed by the president of the Association of Regions of France, who urged all regions to adopt the Charter and implement its initiatives, especially those pertaining to job training and workplace equality. 
Since the Left took over the regional council 2 months after the Charter was announced, it is not surprising that the council's executive and national government appointees worked toward its implementation. For example, Le Drian articulated his commitment to a general principle of non-discrimination between men and women as outlined by the national government in its Equality Charter ('Communication' 2007); and the regional prefect along with the regional Delegate for Women's Rights and Equality used the Charter as a point of reference when implementing the gender mainstreaming provisions of the PASER (Junter and Kieffer, 2006).

Similarly, the international political context was favorable to womenfriendly policies. As previously discussed, European and international organizations promoting regional cooperation and development were responsible for a small number of meaningful women-friendly policies in Brittany $(12 \%)$. First, three EU backed national organizations representing France's various sub-national governments presented the Charter of Decentralized Cooperation for Sustainable Development to the council for its approval. These groups included United French Cities, the French Association of the Council of Communes and Regions of Europe (AFCCRE) and Committee 21, a federation of territorial units that support sustainable development via European integration and decentralized cooperation. The second agreement, Agenda 21, was originally drafted at the United Nations in 1992 and taken up by the French regions after a series of nation-wide meetings on the environment and sustainable development. While both agreements focused on achieving sustainable development goals, their signatories were expected to pursue gender-mainstreamed policies to reach these goals. In contrast, the third agreement, the European Charter for Equality between Men and Women in Local Life, focused exclusively on achieving gender equality in all areas of life. However, like the first agreement, the European Charter originated at the national and European levels. The CCRE drafted the document, and the Council's French section submitted the Charter to France's regions for approval.

The influence of the EU was underscored by interview respondents. A majority of respondents (57\%) said that the EU advanced women's interests in Brittany by serving as a 'pressure point' and a 'funding source.' In the words of one respondent, the EU played 'an undeniable role' diffusing gender equality 'norms' through groups like AFCCRE, and it served as 'a place of comparisons,' which in numerous instances was not to France's advantage. This sentiment was echoed by President Le Drian who (as mentioned above) voiced his belief that the EU, through the European Charter for Equality, helped advance democracy by pursuing equality between men and women. The Breton ratification of EU and $\mathrm{UN}$ agreements in conjunction with the ideology of the council's leftwing governing parties and the national government's 
Equality Charter created a favorable political context at the regional, national and international levels for women-friendly policy making in Brittany.

\section{Critical thresholds and the increase in women-friendly policies}

While this study suggests that critical acts and political context explain the rise in women-friendly policies in Brittany after 2004, it does not provide strong support for the hypothesis pertaining to a 'critical representation threshold.' According to this hypothesis, women's substantive representation in policy terms is most likely to occur when a critical threshold of $15 \%$ is achieved. In Brittany, the number of female regional councilors was $22 \%$ when the Right controlled the council between 1998 and 2004, and 51\% after the 2004 elections when leftwing parties took over the council. If the critical threshold hypothesis is correct, then I should have found evidence of women-friendly policies during both periods because women had broken the 'critical representation threshold' of $15 \%$. However, as was mentioned above, no such policies were enacted when the Right governed the council despite the fact that nearly one-fourth of councilors were women at this time. It was not until 2004, when the Left took over, that pro-women policies were passed. ${ }^{11}$

\section{Conclusion}

By conducting an in-depth case study of Brittany, I have shown that the critical acts of executive officeholders operating within a specific regional, national, and international political context resulted in an increase in the substantive representation of women in policy terms. I have also suggested that sheer numbers do not provide the most convincing explanation for women-friendly policies. As mentioned above, the rightwing Breton regional council did not pass women-friendly policies even when women held nearly one quarter of council seats but the council did pass such policies when women and the Left were in the majority. This finding raises the following questions: Does the critical representation threshold need to be higher when the Right is in power, and if so, how much higher? Conversely, do leftwing governments make women-friendly policy when women are not a majority of councilors, and if so, how low can the threshold go? To answer these questions, it is necessary to examine the policies made by councils where (1) women hold a smaller percentage seats in leftwing councils and (2) there are greater percentages of women in councils controlled by the Right. Only then will we know whether to give greater importance to critical acts and political context rather than sheer numbers when establishing the conditions under which women-friendly policy is most likely to be made. ${ }^{12}$ 
In the meantime, we can consider the impact of the gender parity laws on French women's substantive representation at the regional level. I began this paper by hypothesizing that if there is a connection between the parity law, the increase in the number of female politicians and the passage of women-friendly policies, then parity legislation could be recommended to those seeking gender equity of political outcomes. I also hypothesized that the absence of such a connection would cause scholars to re-think the notion that increases in the number of women holding elective office (via parity legislation) would result in policy that positively affects women. Based on my case study of Brittany, I suggest that while the parity law resulted in a dramatic increase of female officeholders at the regional level, the increased presence of women did not necessarily result in a greater number of women-friendly policies.

However, we should be careful about concluding that gender parity laws have no impact on women's substantive representation. My interviews revealed that Brittany's regional councilors believed that the greater numbers of women in politics were changing the nature of politics in France in general and in Brittany in particular. According to these councilors, gender parity gave the Breton assembly 'visibility and legitimacy,' and it made the council's atmosphere 'less competitive and forceful and more peaceful and balanced.' Additionally, it shook up people's 'habits' by ushering in 'a new mentality, one that equated women with renewal, one that was increasingly shared in French society (especially among young people) and one that French politics cannot go back on.' Finally, the new and numerous women in the Breton regional council put a spotlight on 'social, spatial, temporal and statutory inequalities between men and women,' which influenced the creation of pro-women policies. It seems then that the increase in female officeholders via gender parity laws may have led to a new atmosphere in French regional-level politics and new mentalities among regional councilors, both of which created a favorable climate for the passage of women-friendly policy. Thus, we should be careful about saying that sheer numbers of women are irrelevant to the policy-making process. At the same time, however, the Breton case has demonstrated that critical acts and political contexts are the best predictors for determining whether women's substantive representation in policy terms will increase.

\section{Notes}

1 This work was supported (in part) by a grant from The City University of New York PSCCUNY Research Award Program, for which I am most grateful. I am also indebted to the CUNY Faculty Fellowship Publications Program whose members provided insightful comments on previous drafts of this paper. 
2 In 1999, the French parliament amended the Constitution to favor the equal access of men and women to elected office, and in 2000 it adopted a gender parity law requiring that political parties nominate equal numbers of male and female candidates. Subsequent to the passage of the gender parity law in France, two other European countries passed similar legislation: Belgium in 2002 and Spain in 2007.

3 Despite the dramatic increase in the number of women in municipal and regional councils following the passage of parity, it is said that the law's success is limited because these subnational assemblies are less powerful than those at the national and departmental levels (where the law was largely ignored). I would like to thank Catherine Achin and Sandrine Lévêque for reminding me of this point. For a complete investigation into the successes and failures of the 2000 parity law, see Troupel (2006).

4 While most of the research on French women's substantive representation focuses on the making of women friendly policy, there are also a small number of studies that examine whether French women 'do' politics differently than men (see Achin et al., 2007) and at least one study that investigates whether forces outside elective assemblies affect French women's substantive representation (see Murray, 2007).

5 This definition was adapted from Beckwith and Cowell-Meyers (2007, 556).

6 The CESR (Conseil économique et social régional) is a consultative body of appointed representatives from the region's economic, social, and cultural sectors that gives a non-binding opinion on bills before the regional council (especially those pertaining to budgetary matters).

7 The regional Prefect ensures that regional laws conform with ones made at the national level in part by co-creating and co-financing certain policy programs with the regional council and overseeing the state's administration in the region (services déconcentrés régionaux de l'Etat).

8 The permanent commission (made up of the president, the vice presidents, and representatives from the governing and opposition parties) meets on a monthly basis to carry out the council's work when it is not in session.

9 Jean-Yves Le Drian denied my request for an interview.

10 Bernadette Malgorn did not respond to my request for an interview.

11 When asked whether the increase in the number of female councilors resulted in an increase in women friendly policy, a large majority of respondents ( 86 percent) did not see a causal link between numbers and policies.

12 I am conducting case studies of two other French regions and expect that my research will help clarify the connections between numbers, critical acts, political contexts, and women's substantive representation in policy terms.

\section{References}

Abily, G. and Pondemer, F. (2006) 'Initiatives prises en matière d'égalité Femmes/Hommes, et de lutte contre les discriminations liées au racisme, à l'homophobie... par la Région Bretagne 2004/ 2006', Regional Council of Brittany Document.

Achin, C. et al. (2007) Sexes, genre et politique, Paris: Economica.

Beckwith, K. and Cowell-Meyers, K. (2007) 'Sheer numbers: critical representation thresholds and women's political representation', Perspectives on Politics 5(3): 553-565.

Bereni, L. and Lépinard, E. (2004) 'La parité ou le mythe d'une exception française', Pouvoirs 111: $73-85$.

Bratton, K.A. (2005) 'Critical mass theory revisited: the behavior and success of token women in state legislatures', Politics \& Gender 1(1): 97-125.

Bratton, K.A. and Ray, L. (2002) 'Descriptive representation, policy outcomes and municipal daycare coverage in Norway', American Journal of Political Science 46(2): 428-437. 
Carroll, S. (ed.) (2001) The Impact of Women in Public Office, Bloomington, IN: University of Indiana Press.

Celis, K. (2008) 'Gendering Representation', in A.G. Mazur and G. Goertz (eds.) Politics, Gender, and Concepts: Theory and Methodology, Cambridge: Cambridge University Press, forthcoming.

Communication sur la Chartre de Progrès pour l'Emploi de Qualité (2007) 'Regional Council of Brittany Document'.

Conseil régional de Bretagne (CRB) (1998-2007) Région Bretagne: Actes Administratifs, Rennes: Conseil régional de Bretagne.

Dahlerup, D. (1988) 'From a small to a large minority: women and Scandinavian politics', Scandinavian Political Studies 11: 275-298.

Grey, S., Tremblay, M., Dahlerup, D., Childs, S. and Krook, M.L. (2006) 'Critical perspectives on gender and politics: do women represent women? Rethinking the "critical mass" debate', Politics \& Gender 2(4): 491-530.

Junter, A. and Kieffer, F. (2006) 'Vouloir l'Egalité Dans l'Action Publique: L'exemple du PASER Breton', Economie \& Humanisme 378: 45-47.

Junter-Loiseau, A. (1998) 'La démocratie locale à l'épreuve des femmes: le cas des femmes élues à Rennes', in J. Martin (ed.) La parité: enjeux et mise en oeuvre, Toulouse: Presses Universitaires du Mirail, pp. 97-109.

Lépinard, E. (2006) 'Identity without politics: framing the parity laws and their implementation in French local politics', Social Politics: International Studies in Gender, State and Society 13(1): 30-58.

Lovenduski, J. and Norris, P. (eds.) (1993) Gender and Party Politics, London: Sage.

Lovenduski, J. and Norris, P. (2003) 'Westminster women: the politics of presence', Political Studies 51: 84-102.

Murray, R. (2004) 'Why didn’t parity work?', French Politics 2(3): 347-362.

Murray, R. (2007) 'Is the mere presence of a strong female candidate enough to increase the substantive representation of women?', Paper presented at the European Consortium for Political Research, 7-12 May, Helsinki, Finland.

Norris, P. and Inglehart, R. (2005) 'Women as Political Leaders Worldwide', in S. Thomas and C. Wilcox (eds.) Women and Elective Office, 2nd edn., Oxford: Oxford University Press, pp. 244-263.

Opello, K.A.R. (2006) Gender Quotas, Parity Reform and Political Parties in France, Lanham, MD: Lexington Books.

Ortbals, C.D. (2008) 'Subnational politics in Spain: new avenues for feminist policymaking and activism', Politics \& Gender 4: 93-119.

Phillips, A. (1995) The Politics of Presence, Oxford: Clarendon Press.

Rai, S.M. (2003) 'Institutional Mechanisms for the Advancement of Women', in S.M. Rai (ed.) Mainstreaming Gender, Democratizing the State?, Manchester: Manchester University Press, pp. $15-39$.

Regional Council of Brittany (2006) Le Mag de la Biennale, Rennes: Regional Council of Brittany.

Reingold, B. (2000) Representing Women, Chapel Hill: University of North Carolina Press.

Rieu, A. (1998) 'Femmes élues en milieu rural: quels modes de gouvernance', in J. Martin (ed.) La parité: enjeux et mise en oeuvre, Toulouse: Presses Universitaires du Mirail, pp. 85-95.

Saglio, A. (2004) Pour l'égalité entre les femmes et les hommes en Bretagne, France: Conseil économique et social de Bretagne.

Sineau, M. (1988) Des femmes en politique, Paris: Economica.

Sineau, M. (2001) Profession: femme politique, Paris: Presses de Sciences Po. 
Swers, M.L. (1998) 'Are women more likely to vote for women's issue bills than their male colleagues?', Legislative Studies Quarterly 23(3): 435-448.

Swers, M.L. and Larson, C. (2005) 'Women in Congress: Do They Act as Advocates for Women's Issues?', in S. Thomas and C. Wilcox (eds.) Women and Elective Office, 2nd edn., Oxford: Oxford University Press, pp. 110-128.

Tamerius, K.L. (1995) 'Sex, Gender and Leadership in the Representation of Women', in G. Duerst-Lahti and R.M. Kelly (eds.) Gender Power, Leadership, and Governance, Ann Arbor: University of Michigan Press, pp. 93-112.

Tansey, O. (2007) 'Process tracing and elite interviewing: a case for non-probability sampling', PS: Political Science and Politics 4(4): 765-772.

Thomas, S. (1994) How Women Legislate, Oxford: Oxford University Press.

Troupel, A. (2006) 'Disparités dans la parité', Ph.D. Dissertation, Department of Political Science, Université de Nice-Sophia Antipolis.

Weldon, L.S. (2002) Protest, Policy and the Problem of Violence Against Women, Pittsburgh: University of Pittsburgh Press.

Zimmermann, M.J. (2006) 'Compte Rendu No. 13: I'Audition de Bernadette Malgorn devant la Délégation aux Droits des Femmes et à I'Égalité des Chances entre les Hommes et les Femmes', French National Assembly, Paris, www.assemble-nationale.fr/12/crdelf/05-06. 